\title{
NEW RADIOCARBON DATES \\ FOR THE LATER NEOLITHIC \\ OF NORTHERN SYRIA
}

\author{
P.M.M.G. AKKERMANS
}

ABSTRACT. - A series of fifteen radiocarbon dates has been obtained from the sites of Damishliyya and Sabi Abyad in the Balikh valley of northern Syria. These dates allow a more precise chronological assignment of later Neolithic cultural developments in the region, in particular of the introduction of the earliest pottery and the appearance of the Halaf culture.

RÉSUMÉ. - Quinze nouvelles datations C14 ont été obtenues sur les sites néolithiques récents de Damishliyya et Sabi Abyad, situés dans la haute vallée du Balikh (Syrie du nord). Ces déterminations aideront à établir une chronologie absolue plus précise pour le Néolithique récent, notamment concernant l'introduction des premières céramiques et l'apparition de la culture de Halaf en Syrie du nord.

Recently a number of radiocarbon dates were obtained for samples recovered from the excavations at the Neolithic sites of Damishliyya and Sabi Abyad, both located in the Balikh valley of northcentral Syria. The age determinations were carried out at the Centre for Isotope Research of the University of Groningen ( $\mathrm{GrN}$ nos.) or through Accelerator Mass Spectrometry (AMS) at the Physical Laboratory of the University of Utrecht (UtC nos.). The dates, fifteen in total, add in a significant way to our understanding of the absolute chronology of later Neolithic Syria and adjacent regions (1). Basically these dates serve to date local cultural developments at the sites of excavation and associated changes in overall settlement organisation and material culture. Especially at the site of Sabi Abyad the dates closely agree with the stratigraphic sequence and thus provide a reliable basis for reference in chronological terms. However, the newly retrieved radiocarbon results have a much wider impact, beyond the individual sites, since they allow a more precise dating of two major innovations in material culture, viz. (a) the introduction of the earliest ceramics in the region and (b) the appearance of carefully made painted pottery generally known as Halaf. The former innovation seems at first sight hardly to have touched the local Neolithic communities in a substantial manner: apart from the appearance of pottery, virtually no changes in settlement layout and community organisation or in material culture appear to have taken place (basically the earlier Pre-Pottery Neolithic B way of life is maintained) (2). The introduction of fine painted pottery, however, seems

(1) In order to adjust the newly retrieved dates to the already existing chronological frameworks (and so to avoid general confusion) all dates will be used in a conventional manner, i.e. uncalibrated. See Table 1 for calibrated dates (when available),

(2) AKKERMANS, 1988, 1989b, 1990 to have been associated with major changes in Neolithic society. It coincided with the rise of the Halaf culture, which spread within a rather short time over a vast region and which, beside its handsome pottery, is characterised by circular buildings (tholoi) and a variety of typical beads, amulets and figurines. The introduction and further development of Halaf took place at a time of major changes in people-and-land relationships, the main ones being an increase in population, a continuous trend towards a dispersed settlement system of small villages and seasonal camp sites, and a twofold exploitation of the natural environment with, on the one hand, intensive agriculture and, on the other hand, extensive animal husbandry and hunting (3).

Originally, and on the basis of the results of the 1970 excavations at Tell Assouad in the upper Balikh region, the introduction of pottery in northern Syria was claimed to have taken place somewhere around the middle of the 7 th millennium B.C. (4). The soundings at Assouad led to the distinction of eight levels of occupation, of which the basal levels VIIIVII were without architecture but with pottery, whereas the upper levels VI-I yielded mud-brick remains but no ceramics (5). A sample from the basal, pottery Neolithic level VIII suggested a date around 6500 B.C., whereas another one, from the upper, supposedly aceramic Neolithic level III, yielded a date around 6700 B.C. (6). However, in recent years the early dates presented by the Assouad samples have been repeatedly questioned (7), a doubt which seems

(3) Ibid.

(4) CAUVIN, 1974. But see CAUVIN, 1987 for a modified view.

(5) CAUVIN, 1972

(6) CAUVIN, 1974: 203; a third sample from level III indicated a date of around 10,000 B.C. and was rejected.

(7) LE MIERE, 1979: 40; CAUVIN, 1987: 333-34. 
to be supported by evidence from other excavated Syrian sites, like Bouqras and Abu Hureyra. Here the earliest pottery seems to have appeared at the very end of the 7 th or the beginning of the 6 th millenium B.C. At Abu Hureyra small quantities of pottery were found in the topmost levels (phase III), marked by some mud-brick walls and numerous shallow pits filled with occupation debris. The latest radiocarbon date from the lower, aceramic levels is $6240 \pm 77$ B.C. and soon afterwards the first ceramics appeared at the site (8). The pottery from Abu Hureyra consists of a plain coarse ware which is straw-tempered and crumbly in texture. Most of the sherds seem to have been burnished to some degree and some sherds showed traces of red paint. In general, this pottery seems to be closely related to that from the Balikh sites. It has been claimed (9) that the pottery from Abu Hureyra, Tell Assouad and associated Balikh sites known only from surface reconnaissances is largely identical to the ceramics found at Bouqras in eastern Syria. However, Le Mière (10) has clearly shown that the Bouqras pottery belongs to a different tradition and more closely resembles the ceramics of sites like Umm Dabaghiyah, Tell Sotto and Yarim Tepe I in Iraq. Pottery at Bouqras appeared in mixed deposits in the "virgin-soil squares" from level 7 onwards but the larger part of it was found in the topmost southwestern part of the site. A number of radiocarbon dates from Bouqras suggest that the pottery found in the upper levels 7-1 of the "virgin-soil squares" can be dated around 6100-5900 B.C., whereas the ceramics from the southwestern area are of considerably later date, i.e. around 5600-5500 B.C. (11). Probably the pottery found at Bouqras for the larger part succeeds that recovered from Assouad, Abu Hureyra and other sites further west.

A rather late date, i.e. around 6100/6000-5700 B.C., for the earliest Pottery Neolithic of northern Syria is also indicated by some recently obtained radiocarbon dates from Damishliyya, a small Neolithic site on the west bank of the river Balikh. At least seven occupation layers were recognised during excavation, each characterised by small rectangular mud-brick buildings. The basal strata 1-2 can be termed Pre-Pottery Neolithic, whereas the upper levels 3-7 yielded small numbers of coarsely finished ceramics with little variety in shape (12). The present evidence suggests that Tell Assouad and Damishliyya were largely identical in material culture and there can be little doubt that both sites were simultaneously occupied. Three dates are available from Damishliyya, all coming from a large pit ascribed to the topmost strata 5-7. One sample was taken from charcoal, the others from burnt vegetable

(8) MOORE, $1982: 15$.

(9) CAUVIN, 1974; MOORE, 1975, 1982; COPELAND, 1979.

(10) LE MIERE, 1983, 1986.

(11) LE MIERE, $1986: 120-21,253-57$

(12) AKKERMANS, 1986/87, 1988. inclusions in two sherds (13). The charcoal sample yielded a date of $5750 \pm 90$ B.C., closely supported by one of the sherd samples indicating $5720 \pm 60$ B.C. The other sherd sample, however, is considerably older, suggesting a date of $5970 \pm 110$ B.C. These age difference may be due to the nature of the context from which the samples were taken: some mixing of artefacts of various date can well be expected in the case of refuse pits. It may also be the case that the pit was in use for a considerable period of time, particularly if one takes into account its huge size and depth (the sherds came from different elevations). Whatever the case, it seems clear that the Damishliyya-Assouad pottery is, indeed, of much later date than suggested originally by the Assouad radiocarbon samples and that it is in much closer agreement with the available dates from the sites along the Euphrates. Originally, the pottery of Tell Assouad was compared by its excavator to that of Amuq phases A-B (14), but both Copeland and Le Mière have correctly stated that the Assouad and related Balikh pottery are not similar to the Amuq and Levantine Dark-Faced Burnished Ware; they suggest that the pottery from Tell Assouad, and therefore the comparable ceramics from Damishliyya, preceded the Amuq A assemblage (15). However, according to some radiocarbon dates from Ramad III and Labwe II-A, Amuq A pottery appeared in the early 6th millennium, i.e. around 6000-5900 B.C. (16), and when taking the Damishliyya dates into account this pottery may therefore very well be contemporary to our Balikh ceramics. So far only a few parallels have been found outside the Balikh area for the ceramic assemblages from either Tell Damishliyya or Tell Assouad. A strong regional variability in pottery development is indicated. In the Balikh region itself, intersite differences are noticeable, which are to be expected within a domestic mode of pottery production (17).

In the light of the Damishliyya dates, it appears that the sites of Damishliyya and Assouad were deserted around 5700 B.C. At that time, numerous other settlements in the Balikh valley were also abandoned and a flourishing Pottery Neolithic society seems to have come to an end (18). It is tempting to relate this collapse of local Neolithic society to the general trend towards community desertion in the early 6th millennium B.C. (the socalled hiatus palestinien), but I strongly feel that a similar gap in occupation was in fact non-existent

(13) The age determination was done through Accelerator Mass Spectrometry (AMS) at the Physical Laboratory of the University of Utrecht. Of each sherd, three samples were taken for analysis; the data presented here are an average.

(14) CAUVIN, 1972. Later Cauvin rejected this view and agreed with the comments brought forward by LE MIERE, 1979; cf. CAUVIN, 1987

(15) COPELAND, $1979: 266$; LE MIERE, $1979: 38$

(16) MOORE, 1982.

(17) AKKERMANS, 1990.

(18) AKKERMANS, 1989b, 1990. 


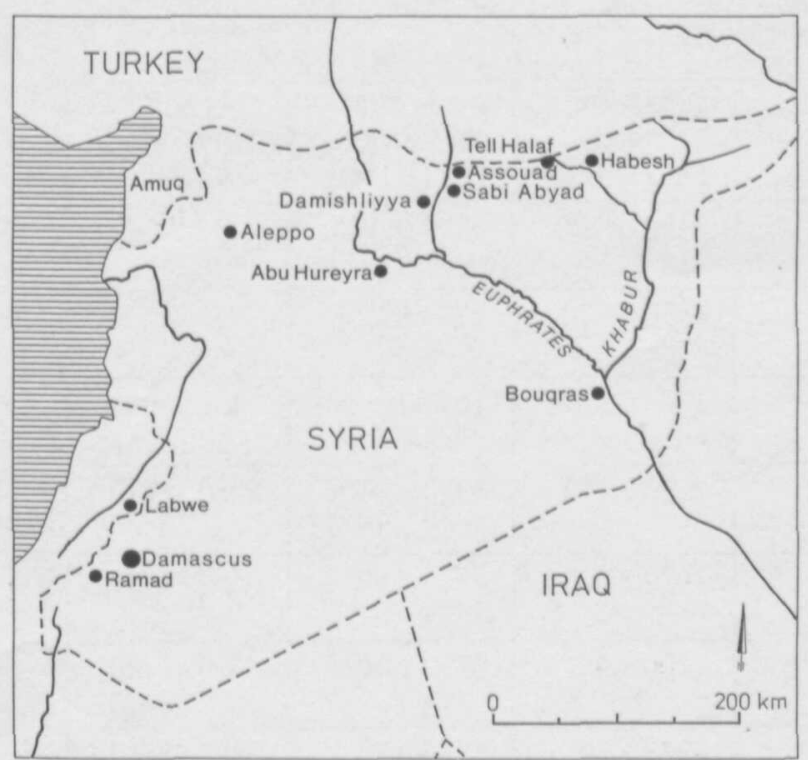

FIG. 1. - Location of the three Neolithic Balikh sites with radiocarbon dates, and other Syrian sites mentioned in the text.

in northern Syria. Part of the assumed trend towards site abandonment in vast areas of Syria and the Levant at this time (19) is without doubt in agreement with the present state of research, although, for that matter, we do have evidence that numerous settlements were given up in the Balikh valley as well, the reasons for which are still unclear. On the other hand, although many sites were abandoned, the present evidence suggests that the valley as a whole was not left uninhabited; occupation in the region seems to have contracted to several larger sites. At present, only a few sites indicate a continuous occupation throughout the 6th millennium B.C., one of which is Sabi Abyad.

Sabi Abyad is located about three kilometres northeast of Damishliyya. The site covers an area of about four hectares and has yielded evidence of permanent occupation for a considerable period of time (20). Three major phases of occupation have been recognised, viz. a pre-Halaf Neolithic phase (Levels 8-7), followed by a transitional stage (Levels 6-4) and a topmost Early Halaf period (Levels 3-1).

At present, twelve radiocarbon dates are available from Sabi Abyad (Table 1). Four samples stem from the northeastern mound (UtC-1010, UtC-1011, UtC1012, GrN-16806), whereas the remainder comes from the southeastern area of excavation. With two exceptions (sample GrN-16801, which is definitely too old, and sample UtC-1010, which seems to be too young), the samples are in agreement with the stratigraphic sequence and as such seem to be highly reliable.

(19) See, for example, MELLAART, 1975: 67-69; MOORE, 1983 : 99.

(20) For a general introduction to the site, see e.g. AKKERMANS, 1987, 1989b, 1990.
The earliest phases of occupation so far uncovered at Sabi Abyad seem to date from around 5300 B.C., but since virgin soil has not yet been reached, it is expected that earlier levels will be found. Some sherds closely resembling the Assouad-Damishliyya pottery of the early 6 th millennium were found on the surface of the site and, in disturbed contexts, in the trenches of excavation. These ceramics strongly plead for a continuous occupation at Sabi Abyad throughout the 6th millennium B.C. The lowest levels thus far reached in excavation must have been contemporary to phase B of the Amuq in western Syria. The best comparisons are found in the characteristic Amuq Dark-Faced Burnished Ware, which occurred in small quantities at Sabi Abyad and which was found on the surface of some other sites in the Balikh region (21). The Dark-Faced Burnished Ware vessels differ from the other burnished pottery in shape, temper, colour and decorative pattern, and clay analyses have made it clear that these vessels are import products from western Syria or southeastern Turkey (22). In the Syrian Jezirah the closest parallel to the earliest ceramics of Sabi Abyad is probably supplied by the Altmonochrome wares of Tell Halaf and Tell Habesh (23).

The remaining figures from Sabi Abyad date either from the "transitional" period from the Alt monochrome-like Neolithic into the Halaf period, dated around 5200/5150-5100 B.C., or from the topmost Early Halaf period which can now be firmly placed between about 5100-5000 B.C. Conventionally, Halaf is said to begin around the middle of the 6th millennium B.C. but this view can no longer be maintained. The present data suggest that the often-mentioned figure of $7570 \pm 35$ BP (5620 B.C.) from Tell Halaf (24), said to date the transition from Altmonochrome to Halaf, is much too old and can safely be rejected (25). Interestingly enough, the "transitional" period is characterised by, among other things, the appearance of carefully made and busily painted (sometimes painted-and-incised) ceramics, some of which closely resemble Samarran pottery from northcentral Iraq (26). Apparently this Samarra-like pottery preceded the appearance of true Halaf ceramics at the site. Samarran or Samarra-derived pottery is still found in the Early Halaf period, when characteristic Samarra traits occasionally appear in combination with Halaf features even on the same vessel (27). A number of radiocarbon dates from Tell as-Sawwan and related sites suggest a date in the later 6th millennium, i.e. about 5300-5000 B.C., for the Classical Sa-

(21) AKKERMANS, 1990

(22) LE MIERE, 1989

(23) Cf. VON OPPENHEIM and SCHMIDT, 1943; DAVIDSON, 1977.

(24) VOGEL and WATERBOLK, 1964.

(25) Earlier, WATKINS and CAMPBELL, 1987 : 444, among others, had already expressed strong doubts regarding the coriectness of the Tell Halaf sample.

(26) AKKERMANS, 1989a, 1990.

(27) ibid., fig. IV : 22, nos. 152, 158. 
TABLE 1

Radiocarbon dates from later Neolithic sites in the Balikh valley, Syria (note: dates of Assouad after Cauvin 1974).

\begin{tabular}{|c|c|c|c|c|c|c|}
\hline SITE & LAB. NO. & MATERIAL & $\begin{array}{l}\text { LEVEL/ } \\
\text { STRATUM }\end{array}$ & $\begin{array}{l}\text { CONVEN- } \\
\text { TIONAL } \\
\text { DATE B.P. }\end{array}$ & $\begin{array}{l}\text { CONVEN- } \\
\text { TIONAL } \\
\text { DATE B.C. }\end{array}$ & $\begin{array}{l}\text { CALIBRA- } \\
\text { TED } \\
\text { DATE B.C. }\end{array}$ \\
\hline \multirow[t]{3}{*}{ Assouad } & Mc-864 & & VIII, 1 & $8450 \pm 120$ & $6500 \pm 120$ & \\
\hline & Mc-865 & & III, 1 & $8650 \pm 120$ & $6700 \pm 120$ & \\
\hline & Mc-607 & & VI & $12,500 \pm 160$ & $10,550 \pm 160$ & \\
\hline \multirow[t]{3}{*}{ Damishliyya } & $\begin{array}{l}\text { UtC-1094/ } \\
1095 / 1096\end{array}$ & $\begin{array}{l}\text { chaff in } \\
\text { sherd }\end{array}$ & $5-7$ & $7920 \pm 110$ & $5970 \pm 110$ & $7050-6610$ \\
\hline & $\begin{array}{l}\text { UtC-1097/ } \\
1098 / 1099\end{array}$ & $\begin{array}{l}\text { chaff in } \\
\text { sherd }\end{array}$ & $5-7$ & $7670 \pm 60$ & $5720 \pm 60$ & $6560-6440$ \\
\hline & UtC-1124 & charcoal & $5-7$ & $7700 \pm 90$ & $5750 \pm 90$ & $6610-6440$ \\
\hline \multirow[t]{12}{*}{ Sabi Abyad } & GrN-16804 & burnt grain & 1 & $6975 \pm 30$ & $5025 \pm 30$ & $5951-5768$ \\
\hline & GrN-16800 & charcoal & 2 & $7005 \pm 30$ & $5055 \pm 30$ & $5959-5818$ \\
\hline & GrN-16801 & burnt seeds & 3 & $7465 \pm 35$ & $5515 \pm 35$ & $6390-6189$ \\
\hline & GrN-16802 & burnt seeds & 3 & $7065 \pm 30$ & $5115 \pm 30$ & $5977-5818$ \\
\hline & GrN-16803 & burnt seeds & 4 & $7075 \pm 25$ & $5125 \pm 25$ & $5979-5889$ \\
\hline & UtC-1008 & charcoal & 4 & $6930 \pm 80$ & $4980 \pm 80$ & $5954-5664$ \\
\hline & UtC-1009 & burnt seeds & 8 & $7080 \pm 80$ & $5130 \pm 80$ & $6074-5883$ \\
\hline & GrN-16805 & burnt wood & 8 & $7145 \pm 30$ & $5195 \pm 30$ & $6077-5976$ \\
\hline & UtC-1010 & burnt wood & $\begin{array}{l}\text { (Halaf n.e. } \\
\text { mound) }\end{array}$ & $6670 \pm 100$ & $4720 \pm 100$ & $5640-5480$ \\
\hline & UtC-1011 & burnt wood & $\begin{array}{l}\text { (pre-Halaf } \\
\text { n.e. mound) }\end{array}$ & $7150 \pm 90$ & $5200 \pm 90$ & $6090-5960$ \\
\hline & UtC-1012 & charcoal & $\begin{array}{l}\text { (pre-Halaf } \\
\text { n.e. mound) }\end{array}$ & $7170 \pm 90$ & $5220 \pm 90$ & $6100-5970$ \\
\hline & GrN-16806 & charcoal & $\begin{array}{l}\text { (pre-Halaf } \\
\text { n.e. mound) }\end{array}$ & $7225 \pm 30$ & $5275 \pm 30$ & $6097-6003$ \\
\hline
\end{tabular}

marra (28). When comparing these figures with both the radiocarbon dates and the ceramic sequence of Sabi Abyad, it not only becomes clear that the rise of Samarra in Iraq must have preceded that of Halaf in Syria but also that both cultural complexes must have been in existence contemporaneously for at least some time.

Interestingly enough, whereas at present no direct relationship between a pre-Halaf stage and the Halaf period can be established for northern Me-

(28) Tell as-Sawwan levels IIIA to V; see, e.g., MELLAART, 1975 : 154 ; COPELAND and HOURS, 1987 : 407. sopotamia (29), such a link now does exist for the Syrian Jezirah. Tell Sabi Abyad has given solid proof of a gradual and uninterrupted, local development of Halaf out of an earlier Neolithic culture, and in this

(29) So far, any links between Halaf and Hassuna appear to have been based on incorrect chronological assignments. Actually, at all the excavated sites yielding both Hassuna and Halaf levels of occupation, like Tell Hassuna, Hajjiluk, Tell Azzo, Nineveh, Yarim Tepe I and Kharabeh Shattani, it appeared that the Halaf strata belonged to the later stages of the Halaf period, which clearly indicated a hiatus in occupation. Cf. COPELAND and HOURS, 1987 : 407; WATKINS and CAMPBELL, 1987: $433 \mathrm{ff}$. 
respect seems to confirm the (admittedly poorly founded) sequences provided earlier by Tell Halaf and Tell Habesh near the Syro-Turkish border. At the latter sites, the basal levels yielded so-called Altmonochrome pottery exclusively, at a later stage followed by a mixture of both Altmonochrome and painted Halaf pottery until in the upper levels the Altmonochrome finally disappeared (30). In this respect, and when taking into account that Halaf in Mesopotamia does not seem to appear before about 5000 B.C. (31), it seems clear that the Syrian Jezirah definitely forms part of the Halaf heartland, perhaps even constitutes the region of origin (32).

\section{Peter M.M.G. AKKERMANS \\ National Museum of Antiquities P.O. BOX 11114 2301 EC Leiden, the Netherlands}

\section{BIBLIOGRA PHY}

\section{AKKERMANS P.M.M.G.}

1986/87 Excavations at Tell Damishliyya, A Neolithic Settlement in the Balikh Valley, Northern Syria. Annales Archéologiques Arabes Syriennes 36/37: 40-66.

1987 A Late Neolithic and Early Halaf Village at Sabi Abyad, Northern Syria. Paléorient 13,1: 23-40.

1988 The Soundings at Tell Damishliyya. In : VAN LOON M.N. (ed.) : Hammam et-Turkman I : 19-67. Istanbul : NHAI.

1989a The Prehistoric Pottery of Tell Sabi Abyad. In : AKKERMANS P.M.M.G. (ed.) : Excavations at Tell Sabi Abyad: 77-213. BAR Int. Ser. 468. Oxford.

1989b The Neolithic of the Balikh Valley, Northern Syria ; A First Assessment. Paléorient 15,1: 121-133.

1990 Villages in the Steppe - Later Neolithic Settlement and Subsistence in the Balikh Valley, Northern Syria. Amsterdam : The University of Amsterdam.

\section{AURENCHE $\mathrm{O}$, and EVIN $\mathbf{J}$.}

1987 List of 14C Dates from the Archaeological Sites of the Near East from 14,000 to 5700 BP. In : AURENCHE O. et al. (ed.) : Chronologies in the Near East : 687-744. BAR Int. Ser. 379:687-744. Oxford et Maison de l'Orient, Lyon.

BRAIDWOOD R.J. and BRAIDWOOD L.S.

1960 Excavations in the Plain of Antioch I. OIP LXI. Chicago : University of Chicago Press.

\section{CAUVIN J.}

1972 Sondage à Tell Assouad (Djézireh, Syrie). Annales Archéologiques Arabes Syriennes 22: 85-88.

1974 Les débuts de la céramique sur le Moyen-Euphrate nouveaux documents. Paléorient 2,1: 199-205.

(30) VON OPPENHEIM und SCHMIDT, 1943 : 25 ; DAVIDSON, 1977

(31) As evidenced, for example, by a recently obtained date of $6930 \pm 60 \mathrm{BP}$ at Arpachiyah; HIJARA et al., 1980:144. For a detailed account on (later) Halaf radiocarbon chronology, see e.g. WATKINS and CAMPBELL, 1987; COPELAND and HOURS, 1987. A long list of Halaf radiocarbon dates is presented by AURENCHE and EVIN, 1987.

(32) See AKKERMANS, $1990: 293-98$ for a more detailed account on this matter. However, Early Halaf painted ceramics closely resembling those of Sabi Abyad have also been found recently in northern Iraq (S. CAMPBELL, Edinburgh, pers. comm.).
Chronologie relative et absolue dans le néolithique du Levant nord et d'Anatolie entre 10.000 et 8.000 BP. In : AURENCHE O. et al. (ed.) : Chronologies in the Near East. BAR Int. Ser. 379: 327-342. Oxford et Maison de l'Orient, Lyon.

COPELAND L.

1979 Observations on the Prehistory of the Balikh Valley, Syria, during the 7th to 4th Millennia B.C. Paléorient $5: 251-275$.

COPELAND L. and HOURS F.

1987 The Halafians, Their Predecessors and Their Contemporaries in Northern Syria and the Levant: Relative and Absolute Chronologies. In: AURENCHE O. et al. (ed.) : Chronologies in the Near East. BAR Int. Ser. 379 : 401-425. Oxford et Maison de l'Orient.

\section{DAVIDSON T.E.}

1977 Regional Variation within the Halaf Ceramic Tradition. Edinburgh: The University of Edinburgh.

HIJARA I.H. et al.

1980 Arpachiyah 1976. Iraq 42: 131-154.

LE MIERE $M$.

1979 La céramique préhistorique de Tell Assouad, Djézireh, Syrie. Cahiers de l'Euphrate 2: 4-76. Valbonne: CNRS-CRA.

1983 Pottery and White Ware. In : AKKERMANS P.A. et al. : Bouqras Revisited: Preliminary Report on a Project in Eastern Syria. Proceedings of the Prehistoric Society $49: 351-354$.

1986 Les premières céramiques du Moyen-Euphrate. Lyon: Université Lumière-Lyon 2.

1989 Clay Analyses of the Prehistoric Pottery : First Results. In : AKKERMANS P.M.M.G. (ed.) : Excavations at Tell Sabi Abyad. BAR Int. Ser. 468: 233-235. Oxford.

MELLAART J.

1975 The Neolithic of the Near East. London: Thames and Hudson.

MOORE A.M.T.

1975 The Excavation of Tell Abu Hureyra in Syria : A Preliminary Report. Proceedings of the Prehistoric Society 41: 50-77.

1982 A Four-Stage Sequence for the Levantine Neolithic, ca. 8500-3750 B.C. Bulletin of the American Schools of Oriental Research 246: 1-34.

1983 The First Farmers in the Levant. In: YOUNG T.C. et al. (eds.): The Hilly Flanks and Beyond. SAOC 36: 91-111. Chicago: The University of Chicago.

VOGEL J.C. and WATERBOLK H.T.

1964 Groningen Radiocarbon Dates V. Radiocarbon 6: 349-369.

VON OPPENHEIM M. und SCHMIDT H.

1943 Tell Halaf I-die prähistorischen Funde. Berlin : Walter de Gruyter and Co.

WATKINS T. and CAMPBELL S.

1987 The Chronology of the Halaf Culture. In : AURENCHE O. et al. (eds.) : Chronologies in the Near. East. BAR Int. Ser. 379: 427-464, Oxford et Maison de l'Orient, Lyon. 